\title{
Andrzej Wierciński, Existentia Hermeneutica: Understanding as the Mode of Being in the World, LIT, Zürich 2019, pp. 512.
}

Andrzej Wierciński's Existentia Hermeneutica: Understanding as the Mode of Being in the World is absolutely innovative in its reflection on the hermeneutic relationship between philosophy and theology. It represents a profound analysis of the whole tradition of philosophical hermeneutics and Catholic theology, which drew upon the former for a new account of the problematic of faith.

The twofold hermenutical strand (both philosophical and theological) is a source of inspiration and strength for Wierciński, particularly to affirm the meaning and interest of a renewed theology, able to reflect on the anthropological question of faith. In Wierciński's work, consideration of the theological problematics within the framewok of philosophical hermeneutis is made possible by, and startsfrom a hermeneutical anthropology that is based on human finitude and its fundamental questions. According to the author, hermeneutics is not a methodology of the human sciences, as it had been within the horizon of Romanticism and the birth of historical consciousness. On the contrary, following Hans-Georg Gadamer's lead the author argues that hermeneutics is a practical and political philosophy. As a form of thought that defends - from Gadamer onwards - the openness to the other as a fundamental anthropological trait, hermeneutics now pronounces, according to Wierciński, the relationship between philosophy and theology. Indeed, after Gadamer and Paul Ricoeur hermeneutics opens not only the space between the self and the other but also between the human and the divine, that is between Philosophy and Theology. 
According to Existentia Hermeneutica, Revelation and the hermeneutical insistence on the primacy of interpretation are by no means opposing approaches to the one problem. On the contrary, hermeneutics is a fundamental mediation between philosophy and theology. In particular, it links problems and issues raised in the philosophical and theological traditions to some very concrete problems concerning their contemporary applications. In this way, hermeneutics helps preserve important theological and philosophical insights. Wierciński's work acknowledges that Martin Heidegger postulated the mutual exclusion of philosophy and theology. However, the author argues that such a thesis should be rethought hermeneutically. For Wierciński, the mutual exclusion of philosophy and theology is unsustainable. Following Gadamer and Ricoeur, the author argues that any methodological division of these disciplines is unsustainable, as it results in their separation from one another. He refers to Heidegger's transition from Catholicism to Protestantism, as well as to his biting critique of Scholasticism, which, in his opinion, confined philosophy and theology to the primacy of the dominant theoretical consciousness. Wierciński reminds us that according to Heidegger theology needs to return to its origins, that is to the faith in the New Testament. Indeed, for Heidegger the Catholic notion of faith and the fundamental Christian beliefs presuppose theoretical formulations of the divine that resemble a metaphysical conceptualization. Thus, a philosophy of religion based on this theological presupposition made no sense at all to Heidegger. He wanted to deconstruct the theological tradition and inaugurate a theology to come, while at the same time appropriating the theological and mystical language that was available to him. It is Heidegger's disciples, Bernhard Welte and Gustav Siewerth, together with the great names in contemporary philosophical hermeneutics (most notably Gadamer and Ricoeur) who enable Wierciński to overcome the metaphysical horizon of any separation between theology and philosophy and to argue for their fundamental hermeneutic relationship with each other. Wierciński's book is based on the works of Welte and Siewerth and seeks to affirm 
that God is always present in Heidegger's thought. It also argues that Welte and Siewerth never ceased trying to find (and to try finding) the divine in Heidegger, which is not the Being itself.

With reference to Gadamer, whose thought is examined at length and in depth in this book, the author underlines the importance of the Heideggerian hermeneutics of facticity, thus implicitly admitting the influence exerted upon him by the young Heidegger's theological writings, in particular his interpretation of the Aristotelian phronesis. Gadamer's work lies at the horizon of human praxis. His philosophical hermeneutics is a philosophy of finitude, rather than an abstract theory. Hence, as Wierciński's work rightly points out, the relevance of the ethical question, the problem of deliberation, and the importance of language in Truth and Method, enable us to think about the Christian theology of the Incarnation - and its relation to the Word - from a hermeneutic standpoint. Indeed, Gadamer's work exemplifies the relationship between philosophy and theology when it shows us, against the Greek idea of the separation between thought and language, that only the medieval theology of the Trinity allowed us to think the true human unity that exists between thinking and speaking. As for Ricoeur, to whom Wierciński's work dedicates several very interesting pages, he is the inspiration that allows a believing philosopher and a philosophizing believer to enter into mutual dialogue. The heterogeneity of Ricoeur's thought is valued, and the fact that Ricoeur underlines the importance of a hermeneutics of testimony, which always lies at the horizon of the Christian tradition, is also pointed out. Although Ricoeur is consistent in separating philosophy from his religious belief, the present work nevertheless considers that Ricoeur's faith undoubtedly influenced his philosophy. Furthermore, it acknowledges that the ever-reaffirmed Ricoeurian distinction between philosophy and theology manifests itself clearly in most of his philosophical texts, and that he remains a philosopher of the poetics of faith even when he reflects upon the biblical Revelation. However, Ricoeur is said to know much about contemporary theology, particularly in the field of Protestant 
theology. Wierciński argues that Ricoeur, being consciously aware of the limitations in both philosophy and theology, encourages their coexistence and concludes that contemporary hermeneutics calls for a rethinking of the problematic relationship between philosophy and theology at various levels. In particular, while hermeneutics is an area of knowledge that negotiates its own place between different discourses, it does require that such disputes be reflected upon once more. In the hermeneutic age, philosophy has lost its pretension to speak purely from the point of view of pure reason, or the permission to foster what Wierciński calls 'the incorporation of theology into philosophy.' Indeed, according to Wierciński most of the arguments that deal with the problematic relationship between philosophy and theology were based on the fact that philosophy can free itself from culture, whereas theology is absolutely conditioned by history and culture. Today, hermeneutics must help us recognize that philosophy is a cultural phenomenon just like theology. If either is a way of life for a human being, then neither has a privileged position over the other, as argued in Wierciński's work.

The conclusion of the book is a reflection on poetic revelation, which emphasizes the role of language as a medium for conveying a hermeneutic experience. It also speculates about the future unfolding of hermeneutics.

Given the importance of the topics addressed in this book, the original perspective on the connections between philosophy and theology developed by Wierciński and his whole hermeneutic approach, Wierciński's book is a valuable reading not only for the philosophical community but for the general public as well.

\footnotetext{
MARIA Luísa PortocarRero

mlp600@gmail.com

Departamento de Filosofia, Comunicação e Informação, Faculdade de Letras, Universidade de Coimbra, Largo da Porta Férrerea, 3004-530 Coimbra, Portugal

ORCID: 0000-0002-1288-9535
}

DOI: $10.21697 /$ spch.2020.56.1.33 